\title{
THE EFFECTS OF USING THE WHATSAPP MESSAGES ON ENGLISH LANGUAGE
}

\section{Mr Om P Joshi}

\begin{abstract}
The purpose of this paper is to find out the effect of using the Whatsapp messages on the English language. This is the age of social networking site. The researcher will discuss the effect of Whatsapp messages on English from a structure, grammar, punctuation, code language, symbol usage, emoticon usage, abbreviation, acronym, fusion, coinage of new words, vowel usage etc. The researcher sums-up and reports findings based on the data analysis and interpretation. Along with this, the researcher also enunciates the favourable and adverse effects of Whatsapp messages on English.
\end{abstract}

\section{Introduction:}

The word e-communication is also very important in the field of education and entertaining. 'ecommunication' or 'electronic communication' has emerged as a powerful medium of interaction in modern time. The communication helps in a daily life. It always helps in share the ideas, information, knowledge and so on. As simple as communications seem, much of what we try to communicative to others - and what others try to communicate to us - get misunderstood, which can cause conflict and frustration in a personal and professional relationship.

Short Message Service (SMS) is the most basic communications technology for mobile data transfer and is characterized by the exchange of short alphanumeric text messages between digital line and mobile devices. SMS messaging's key influential factor is affordability. (Techopedia).

\section{Some definitions of communication are as follows:}

As cited by Shalini Verma, 'Peter Little' Defines Communication as

"It is a process by which information is transmitted between individuals and organisations so that an understating response result (Verma)".

As cited by Shalini Verma, 'W.H.Newman'\& 'C.F.Summer' are in the opinion that

"Communication is an exchange of facts, ideas, opinions, or emotions by two or more persons(Verma)". 
So let's believe that

"Communication is the act of which information is shared; such encounters may cover: Desires, Needs, Perceptions, and Knowledge etc."

\section{Literature review:}

This review of literature begins with a short history of writing and journaling and their impact on the writing process. It will continue with the review of the theoretical framework of Siemens's connectivism and research on electronic journaling as a tool that may help students become better writers. (Alsaleem).

1. A paper entitled "Mobile intelligent tutoring systems (ITS)" a paper presented at annual IEEE International conference, 2005 by Bull, Cui, McEnvoy, Reid and Yang(Bull).

2. Mobile learning infrastructure development in developing countries has been the focus of M-learn 2005, held in Cape Town South Africa, between 25-28 October 2005(Barker).

3. Zhang, H., Song, W., \& Burston, J. Re examining the effectiveness of vocabulary learning via mobile phones. Turkish Online Journal of Educational Technology, 10(3), 203-214. Retrievable from http://www.tojet.net (Zhang).

4. Yin, C., Ogata, H., Yano, Y., \& Oishi, Y. Supporting Japanese polite expressions learning using PDA towards ubiquitous learning. The Journal of Information and Systems in Education, 3(1), 33-39. Retrievable from http://yebisu.cc.kyushu-u.ac.jp (Yin).

5. As cited by Burston, Yildiz, S. Use of iPad Applications to Introduce English as a Foreign Language to Young Turkish Learners. 2012 CALICO Symposium, University of Notre Dame, June 14-16, South Bend, Indiana (Burston).

6. Wu, T., Sung, T., Huang, Y., Yang, C., \& Yang, J-C. Ubiquitous English learning system with dynamic personalized guidance of learning portfolio. Educational Technology \& Society, 14(4), 164-180(Wu).

\section{Objectives:}

1. To examine WhatsApp tool used for e-SMS.

2. To study the effects of WhatsApp messages on the English language.

\section{Data Collection, Analysis and Interpretation}

The present research focuses on investigating randomly selected WhatsApp message samples collected by the researcher to analyse the effects of the WhatsApp message for communication and to study the transformation in English language use. Random selection method has been used to select the WhatsApp message. The researcher has collected 50 samples from the WhatsApp message. The researcher has collected from different websites and available in public domain. They are kept blind, and details of authors are kept blind because it is sensitive and very much personal. The sample under each category is about 1500 words.

\section{Software Used:}

The researcher used software namely Grammarly for the analysis and interpretation of the data collected. 


\section{Parameters:}

The researcher decided parameters to analyses collected data. Several parameters were analysed using software like Grammarly.

The parameters for analysis are as follows:

\begin{tabular}{|c|c|c|}
\hline $\begin{array}{l}\text { Sr } \\
\text { No }\end{array}$ & Parameters & Meaning \\
\hline 1 & $\begin{array}{l}\text { Improper punctuation or } \\
\text { punctuation within a clause }\end{array}$ & $\begin{array}{l}\text { Punctuation Errors inside the sentence, either } \\
\text { wrong punctuation or missing punctuation }\end{array}$ \\
\hline 2 & Improper use of prepositions & Inappropriate use of the element in the clause. \\
\hline 3 & $\begin{array}{l}\text { Use of abbreviations/ } \\
\text { acronyms/code language }\end{array}$ & $\begin{array}{l}\text { An error involving abbreviations/ } \\
\text { acronyms/code language. From the initial } \\
\text { components in a phrase or a word. }\end{array}$ \\
\hline 4 & Sentence fragment & $\begin{array}{l}\text { Mistakes made when putting the parts of a } \\
\text { sentence together, hard-to-understand } \\
\text { sentences }\end{array}$ \\
\hline 5 & $\begin{array}{l}\text { Use of emoticons/ } \\
\text { graphics/symbols }\end{array}$ & Any feelings expressed using symbols \\
\hline 6 & $\begin{array}{l}\text { Spelling and improper } \\
\text { capitalisation }\end{array}$ & Misspelled words and wrong capitalisation \\
\hline 7 & Articles & Errors made when using articles \\
\hline 8 & Usage of colloquial greeting & Inappropriate word usage for formal writing \\
\hline 9 & Accidentally confused words & $\begin{array}{l}\text { Errors involving confusing similar words with } \\
\text { different meaning }\end{array}$ \\
\hline 10 & Absence of vowels in words & Vowels are absent in the words \\
\hline 11 & $\begin{array}{l}\text { Infusion of vernacular language/ } \\
\text { Transliteration }\end{array}$ & $\begin{array}{l}\text { To change words into corresponding characters } \\
\text { of another alphabet or language. To } \\
\text { transliterate in any language. }\end{array}$ \\
\hline 12 & Subject and verb agreement & $\begin{array}{l}\text { Errors made in ensuring the subject and verb } \\
\text { agree throughout the sentence }\end{array}$ \\
\hline 13 & Verb form use & Errors made by using the wrong verb form \\
\hline 14 & Improper formatting & Inappropriate usage of formatting \\
\hline
\end{tabular}




\section{Data Analysis:}

\section{Chart of WhatsApp Sample Data Analysis}

\begin{tabular}{|r|l|l|}
\hline Sr No & Name of the Parameters & Frequency \\
\hline 1. & Improper punctuation or punctuation within a clause & 362 \\
\hline 2. & Improper use of prepositions: & 27 \\
\hline 3. & Use of abbreviations/ acronyms/code language & 155 \\
\hline 4. & Sentence fragment & 16 \\
\hline 5. & Use of emoticons/ graphics/symbols & 46 \\
\hline 6. & Spelling and improper capitalization & 55 \\
\hline 7. & Articles & 33 \\
\hline 8. & Usage of colloquial speech & 11 \\
\hline 9. & Accidentally confused words & 10 \\
\hline 10. & Absence of vowels in words & 110 \\
\hline 11. & Infusion of vernacular language/ Transliteration & 12 \\
\hline 12. & Subject and verb agreement & 6 \\
\hline 13. & Verb form use & 8 \\
\hline 14. & Improper formatting & 519 \\
\hline
\end{tabular}

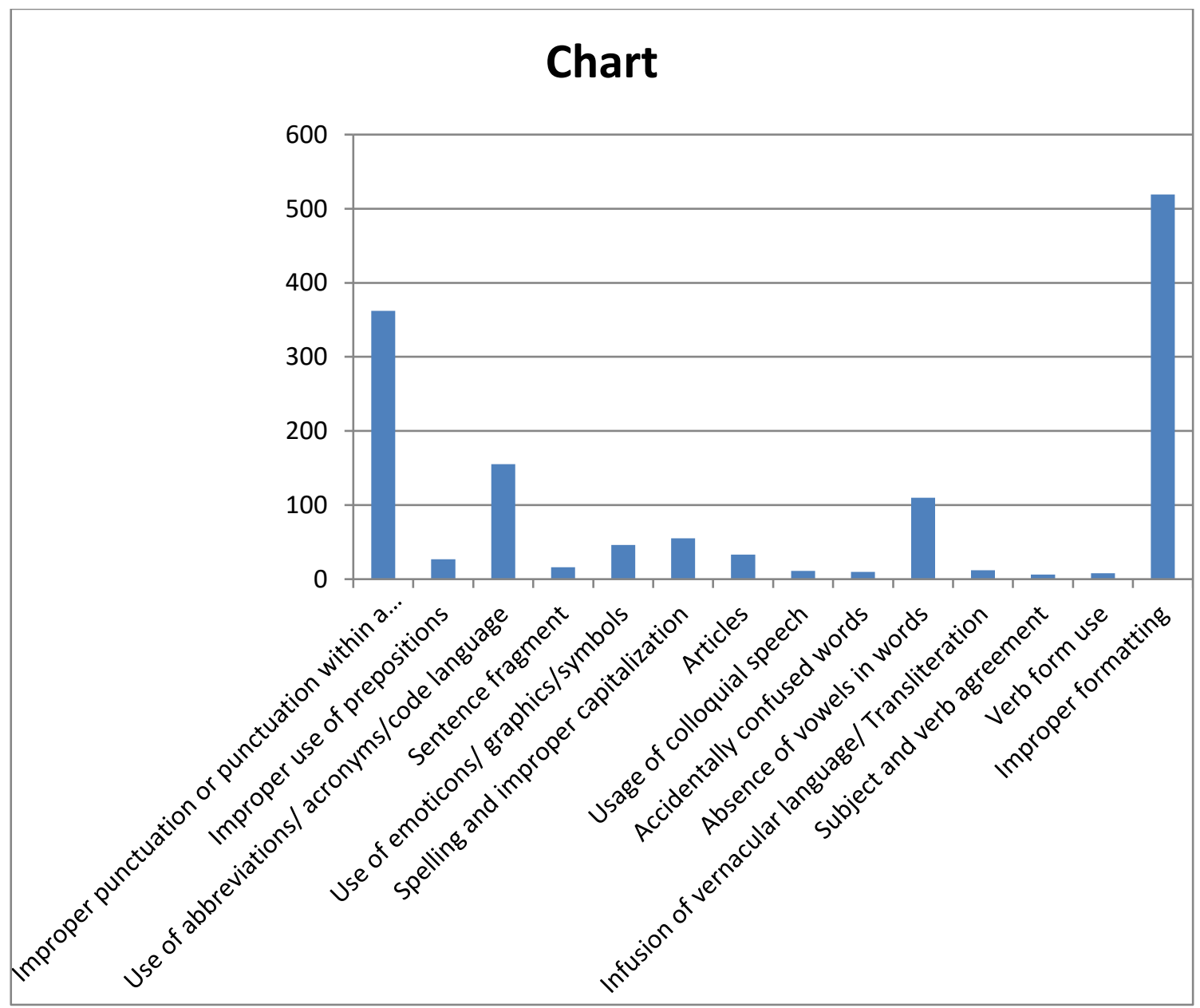




\section{The Results of Data Analysis are as follows}

- The highest number of discrepancies can be found in 'Improper formatting' section showing frequency of 519 .

- This is followed by 'Improper punctuation or punctuation within a clause' procuring frequency of 362 .

- The third highest position goes to 'Use of abbreviations/ acronyms/code language' having frequency of 155 .

- Total number of discrepancies found in whatsapp sample data analysis is 1370 .

\section{Addressing the Research Objectives:}

\section{To examine WhatsApp tool used for e-SMS.}

WhatsApp Messenger is a viral application now a day. It is easily available on iPhone, BlackBerry, Android, Windows Phone and Nokia Smartphone users to exchange text, image, video and audio messages for free. Moreover, to basic messaging, WhatsApp provides group chat and location sharing options.

\section{To study the consequences of Facebook messages on the English language}

According to the result of the data analysis, the percentage of the language errors found in different samples are as follows:

WhatsApp:91\%(1370 out of 1500 words)

$>$ Numbersimilar to pronunciation is used instead of full spelling of the word like: 4 instead of for, 2 instead of to.

$>$ Combinations of numbers and word similar to pronunciation are used instead of full spelling of the word like: g8 instead of great or goodnight.

Most of the users communicate with the use of abbreviations/ acronyms/code language.

\section{Conclusion}

Language developed along with civilizations. Oral language to inscription to printing and from printing to digital. It is found that most of the people use emoticons, symbols, abbreviations, numbers similar in pronunciation to the words instead of spellings, transliteration, the words of their mother tongue, incomplete sentences, wrong spellings etc. on WhatsApp messages. It is one of the major effects of WhatsApp messages on the English Language. 


\section{Works cited}

Alsaleem, Basma Issa Ahmad. The Effect of" WhatsApp" Electronic Dialogue Journaling on Improving Writing Vocabulary Word Choice and Voice of EFL Undergraduate Saudi Students. Arab World English Journal 4.3 (2013).

Barker, Andrea, Greig Krull, and Brenda Mallinson. A Proposed Theoretical Model for M-Learning Adoption in Developing Countries.

Bull, Susan, et al. Roles for mobile learner models." Wireless and Mobile Technologies in Education, 2004. Proceedings. The 2nd IEEE International Workshop on. IEEE, 2004.

Burston, Jack. Mobile-assisted language learning: A selected annotated bibliography of implementation studies 1994-2012. (2013).

“Short Message Service." Www.techopedia.com. Techopedia, n.d. Web. 27 Nov. 2017.

Verma, Shalini. Technical Communication for Engineers. New Delhi: Vikash, 2015.Books.google.co.in. Web. 8 June 2015.

Wu, Ting-Ting, et al. Ubiquitous English Learning System with Dynamic Personalized Guidance of Learning Portfolio. Journal of Educational Technology \& Society 14.4 (2011).

Yin, Chengjiu, et al. Supporting the acquisition of Japanese polite expressions in context-aware ubiquitous learning. International Journal of Mobile Learning and Organisation 4.2 (2010): 214-234.

Zhang, Haisen, S. O. N. G. Wei, and Jack Burston. Reexamining the effectiveness of vocabulary learning via mobile phones. TOJET: The Turkish Online Journal of Educational Technology10.3 (2011).

\section{Mr Om P Joshi Assistant Professor Gandhinagar Institute of Technology}

